\title{
MULTICULTURAL COUNSELLING WITH THE TECHNIQUE OF PARABLE
} A DIACOGNITIVE ANALYSIS

\section{Erni Maria Clartje Efruan ${ }^{1}$, Zummy Anselmus Dami ${ }^{*}$, David Samuel Latupeirissa $^{3}$ and Mesakh Abia Pello Dethan ${ }^{4}$}

\author{
${ }^{1}$ Institut Injil Indonesia, Department of Theology, East Jawa, 65313, Indonesia \\ ${ }^{2}$ Universitas Persatuan Guru 1945 NTT, Faculty of Education, East Nusa Tenggara, 85119, \\ Indonesia \\ ${ }^{3}$ STIBA Mentari Kupang, Department of English Literature, East Nusa Tenggara, 85143, Indonesia \\ ${ }^{4}$ Universitas Kristen Artha Wacana, Department of Theology, East Nusa Tenggara, 85228, \\ Indonesia
}

(Received 29 July 2019, revised 26 November 2019)

\begin{abstract}
The study aimed to increase cultural awareness through multicultural counselling services using the technique of parable. The parable used in the study was the parable of the Good Samaritan, while the method applied in the study was the diacognitive analysis method (dialogue, position, and cognition). Research results have shown that a counsellor who uses a parable technique can make a counselee have multicultural awareness. A counsellor must have data and information relating to the opposition of ethnicity and religiosity. A counsellor should have cultural considerations, cultural knowledge, cultural understanding and cultural competencies. Moreover, most importantly, the counsellor has the compassion to the counselee, because, through 'compassion', there will be a shift from self-independent to self-interdependent, that is to 'be there-for-others'.
\end{abstract}

Keywords: parable, Samaritan, analysis, multicultural, counselling

\section{Introduction}

The concept of multiculturalism stands for two self-concepts, namely selfindependent and self-interdependent [1]. The difference between two selfconcepts affects the way a person sees himself. People who have self-independent prefer to be atomistic themselves. As autonomous/independent individuals, they can decide what is best for themselves. People who have self-independent frequently judge others, which are different, with their criteria in their possession. Different things are experienced by people who have self-interdependent. They have an understanding of the concept of self-contrary to those who have the first self-independent. For those people, actions to other people must be based on the context. Thus, people who have the second self-dependent tend to understand the

\footnotetext{
*Corresponding author, e-mail: zummy.dami@upg45ntt.ac.id
} 
actions of others by connecting them continuously to the external context of the action, and not viewing them using the internal attribution [2].

This concept of self has become the basis of all reflections about multiculturalism. In this spectrum, multiculturalism is not only about identity differences but about everything embedded in culture, which is related to social beliefs and practices. Here, the group can understand whom themselves as well as understand the world. At this level, the difference is no longer only at the level of individual choices, but also the differences in the cultural level. The differences in the cultural level have more complicated since they are related to the cultural authority which is formed and embedded in a system of meaning. Thus multiculturalism is about cultural differences, which is also called as culturally embedded differences [3].

The differences of a self-internalized construction lead to ethnocentrism and religious-centrism bias of multiculturalism. Ethnocentrism and religiouscentrism bias will arise due to independent self-claims. As the consequent, it becomes socio-cultural disruptive or disintegration [4]. In the current study, disruptive or socio-cultural disintegration is projected through the parable of Good Samaritan. In the parable, Jews' opposition to the Samaritans has shown (1) the level of togetherness, (2) the negative prejudice between two cultural views, (3) the low understanding about humanity, (4) the Jews consider the Samaritan worship as unright practice and (5) the Samaritans believed that the holy place was not in Jerusalem but the Mount Gerizim [5-7]. The opposition was attributed mainly to the reason for ethnicity, in which the Jews considered the Samaritans as non-pure Israel people [8-10].

This empirical evidence shows how low the multicultural competencies of Jews towards the Samaritans. Consequently, there was no confession, reverence, and acceptance of Jews to the treasures of the Samaritans' cultural riches. Therefore those two groups of people did not live in harmony. There was no tolerance between them.

The phenomena in the parable also occur nowadays. A phenomenal event in early 2019 about a Catholic named Slamet Jumiarto who was rejected to live in Sub District Karet, village Pleret, Java-Indonesia. Based on an interview published in the local newspaper, the rule that rejects non-Muslim people is local wisdom that has been agreed by residents. The rule itself was issued since October $19^{\text {th }} 2015$ by the Village Community Institute of sub-district Karet, village Pleret, Java-Indonesia. In their rule, the new entrants must be only Muslim [Detik News, April $2^{\text {nd }} 2019$; Tempo, April $2^{\text {nd }} 2019$ ]. The cases presented, as have been stated, were happened in Indonesia as the multicultural nation. It shows that many people in the nation have got low multicultural social competencies [11].

Objectively, according to [12], multicultural competencies are crucial to be mastered by someone as it relates to what is seen, how to understand what to see, and how to express ourselves. Lack of understanding of cultural identity included understanding how it can affect various aspects of life, can be a source of conflict. It is a significant obstacle in one's interpersonal relationships. Furthermore, [12] 
state that often, people do not even realise that their cultural values are different from others [11]. Counting such description above, it is stated that a counsellor should have multicultural competence, and it has to be applied in the counselling process, especially in understanding the cultural context of a counselee [13].

Moreover, the story of the parable of Good Samaritan has also been examined by the previous researchers $[6$, p. 352-351; 14-16]. The four studies that have been conducted before did not discuss the parable related to counselling technique, especially multicultural counselling. This current study examines the role of Jesus as a teacher (counsellor) who had multicultural competencies to assist other people (helping profession) with parable technique.

\section{Methods}

The research method applied in the current study was the qualitative method, while the approach of the research was diacognitive analysis. Diacognitive itself is a conceptual framework for understanding and analysing the events of learning and teaching [17]. This concept is derived from the sense of Paulo Freire, which states that learning and teaching is an event in the process of knowing the broader [18]. The framework consists of three layers. It provides differences as well as a complementary perspective on the learning and teaching events that connect learners with the process of knowing. The three layers, namely dialogue, cognition, and position. Those three can be illustrated as part of a triangle explaining the multicultural counselling events, providing mutual multicultural information, and enriching multicultural perspectives (Figure 1).

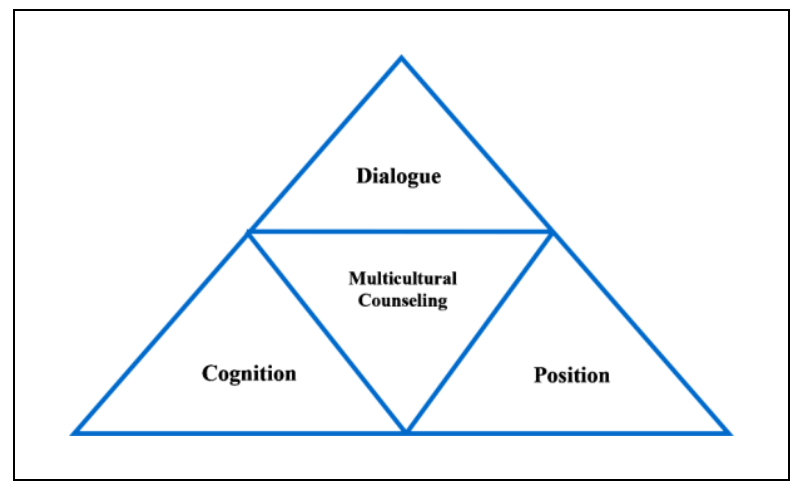

Figure 1. Diacognitive.

The diacognitive framework shows that dialogue, cognition, and position components are mutualism. Interactions between dialogue, cognition, and position are always placed in the context of conversation and power. In the setting of authoritarian education, a student will feel safer since the position of 'I-asquestioner' or 'I-as-not-understand' is unavailable.

The collection of data uses the parable of the Good Samaritan in Luke 10.25-37. Especially, data related to multicultural counselling technique. 


\section{Results}

\subsection{Diacognitive analysis - dialogue}

This dialogue occurred because of two questions that the expert in the law told Jesus. These two questions are questions that trap or drop (Ekpeirazon) Jesus (teacher/counsellor because it contains a veiled motif [15, p. 3]. The motive of this question could mean testing the knowledge of Jesus, or obtaining a charge contrary to the law so that there was a gap to drag Jesus to the court (Luke 11.16, 18.18). At the interpersonal level, the parable originates from the dialogue between Jesus (teacher/counsellor) and an expert in the law (EL/counselee). The parable takes the form of an interchangeably-changing reply to the answers. EL asked his first question, "What shall I do to inherit eternal life?" The teacher answered with a question, "what is written in the law?". EL answered the question: "loving God and loving your brother". Finally, the teacher authorizes EL. The dialogue seems to cease suddenly, ends up in a clear agreement [19] and mentions the approval as the termination of the dialogue. However, EL continued to ask the second question, "and who is my brother?". Responding to the question, the counsellor told a parable as a response. After telling the parable, the counsellor then asked EL a question about the parable that connected it with the second question from EL: "Which of these three men do you think as a brother?" EL replied, "He who has mercy (compassion) on him". The teacher concluded with an instruction, "go and do so".

Jesus, as the teacher, as well as a counsellor, did not answer directly. He created questions for EL to direct EL answering his question. The technique is: first, by drawing the knowledge of the law; second, by interpreting the parable; and third, by using the interpretation to answer both questions.

Jesus was the counsellor who used the dialogue form to lure EL thinking as well as to challenge him drawing his conclusion [20]. He states that it is a kind of strategy for the pedagogy dialogue, which developed by a counsellor as the 'dialogic provocation'. As a distraction, the ontological dialogue would involve students with something that excites and attracts their hearts. Therefore, Jesus, as a teacher/counsellor, used the reverse of this parable [21].

Intrapersonal dialogue, explicitly, refers to two parts, namely: First, EL stands to test the teacher/counsellor (Luke 10.25). There indicates that EL should be involved in the internal dialogue: "How can I test this man? I know, I will ask him...". Second, the phrase, "but to justify himself" (Luke 10.29) gives the impression of an internal conversation such as, "he has shown me that I have known the answer'. 'How do I keep a good name? I will ask him <Who is my brother?>'. Implicitly, this dialogue indicates that the interlocutor is internalising other people and formulating a response of corresponding. As an example, hearing EL's first question, the counsellor had an internal dialogue as follows: 'Why did he ask me that?'. 
Next, in the transpersonal level, the implicit and declarative parable takes an interrogative form to create a concrete story, as well as to stimulate a listener making an interpretation. Furthermore, the parable, semantically, opens and works through a metaphor that requires someone to interpret: "Which of these three men do you think is a brother?". This question requires listeners to participate with the process of producing deeper meaning than only being a passive teaching recipient.

Concerning the intratextual level, in the parable, three characters passed through the half-dead person and who helped a person. A priest and a levite passed by since according to Jewish law, they were not permitted to defame themselves by touching the corpse [22, 23]. Contrary to that, the Samaritan showed compassion, careful attention and responsibility. The situation has become more attractive because Samaritans were regarded as heresies, which were thrown out of the Jewish community. They have no relationship with the Jewish people. The idea of the Samaritans who become a Jewish brother, for sure, is astonishing to the Jewish listeners. The intratextual dialogue among the responses to people who were half dead was then associated with dialogue between the parable and the context of socio-religious listeners.

Finally, this is a dialogue between knowing and doing, understanding something and putting it into practice. In the parable, the question of EL was "What should I do to inherit eternal life?". The question indicated what a questioner would like to know and what to do. On the other hand, the teacher's answer indicated that the relationship between "to know and to do'. As a counsellor, Jesus asked EL "What is written in the law? How did you read it?" The next EL's answer indicated that he has known what the law wanted. Interestingly, the teacher did not cease with the invalidity of the answer. The teacher replied "You have answered correctly" - in other words, the teacher would like to say that 'the questioner has known the answer'.

\subsection{Diacognitive analysis - position}

The position of participants informs their position in the parable. In Figure 2, the position of Jesus as a counsellor and EL is illustrated. Here, counselee took a position as questioner while Jesus took the position of a teacher/counsellor as a person who knew the topic as well as had the authority.

In the question, implicitly, there is a proposal relating to Jesus' statement, that is, 'you are a teacher who can answer'. The teacher chooses not to accept this imposed position. Moreover, the teacher repositioned Himself from the answerer to the questioner. EL accepted this position and submitted the answer: 'Love God and your brother'. Then, EL concluded how to inherit eternal life.

The lingual phenomena of conversation mean that EL is the man who has known what is written in the law and how to manifest it. It reveals that the question is not an authentic investigation of the knowledge for inheriting eternal life, but more to test the teacher/counsellor. The teacher positioned himself as a person who assessed the validity of the question. Next, EL has reversed the 
position of judging to be judged. It can be seen from the statement "You have answered correctly. Do this, and you will live." Here, the teacher positioned the EL as the knower and the one who could act to practice his knowledge (agent).

After that, EL repositioned himself as a questioner by questioning "And who is my brother?" The teacher accepted this position indirectly, and answered the question with a parable. In conclusion of this parable, the teacher took a position as a questioner while EL took a position as answerer. EL accepted this position and stated that the man who has expressed mercy on him is the brother. The description is shown in the following Figure 2.

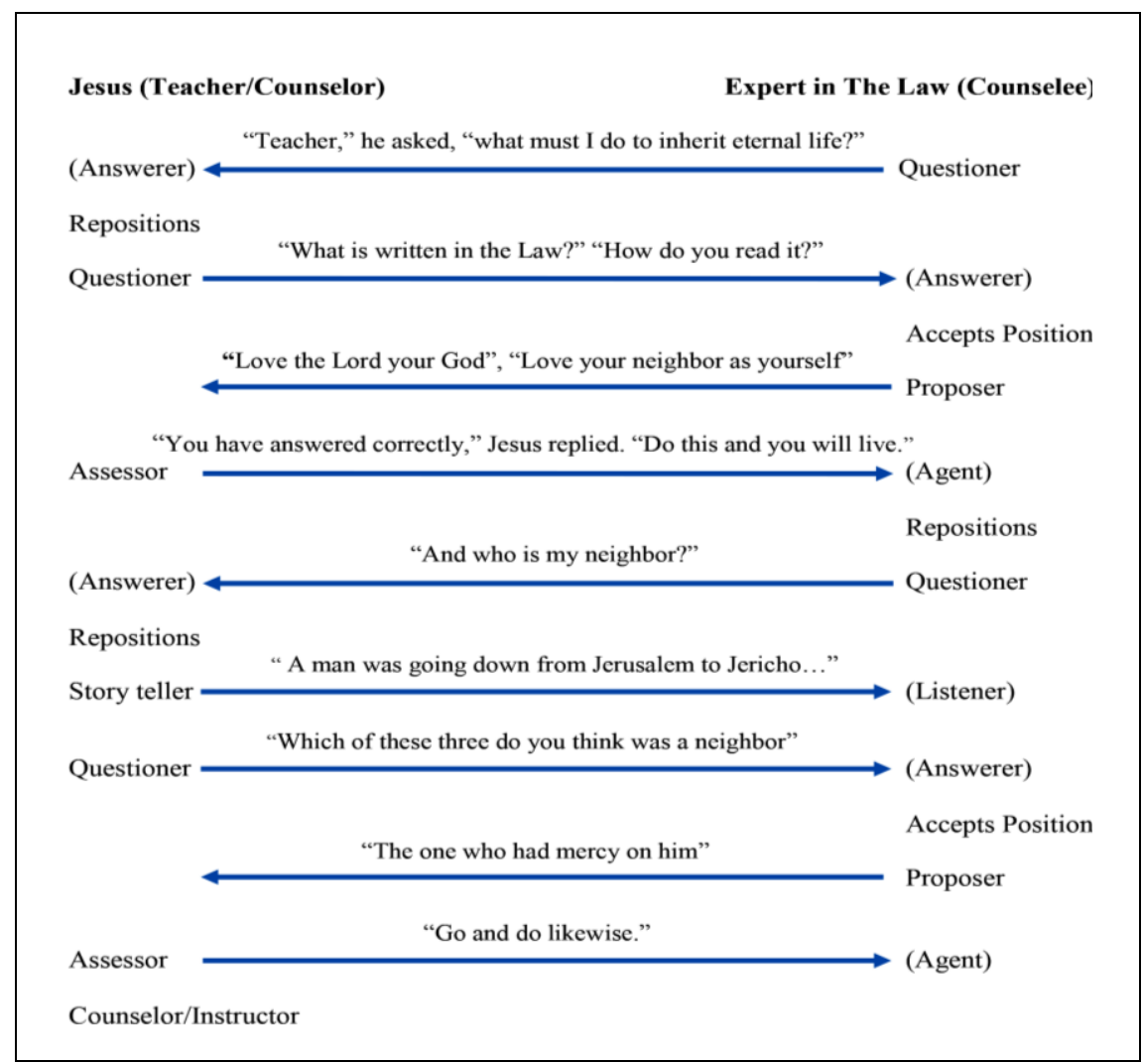

Figure 2. The position in the parable of the Good Samaritan.

\subsection{Diacognitive analysis - cognition}

The first object of cognition was introduced by the EL's question, "What to do to inherit eternal life". Responding to the question, EL acknowledged "Love your God". The acknowledgement revealed what EL has known. The teacher's response shows that the teacher had also known the answer to the EL before he uttered it. Furthermore, the counsellor knew the motivation of EL, which was to test him. 
This dialogue in the parable revealed that the first reversal, as expected by the EL and the listeners (Jews) did not occur. They wanted the counsellor to answer the question "who is my neighbour" directly. They wanted the answer to be general. The general answer, in Israelites cultural view at that time, was Israel people [6].

The Samaritans were identified as blemished people [24]. However, in the parable, those people have been an example of true love (not the priest or levite). This fact was unpleasant for the EL as well as the people of Israel who heard the dialogue. Moreover, this parable questioned people's assumptions about their status and position. It indicated that not who we are but our willingness to be touched on the inside, literally in the entrails, by the sufferings of others and how we act in response that is crucial in loving your neighbour [21] and how the action is more important in showing love to the neighbour.

This parable established a specific relationship between knowing and doing, cognition and acting. It is not enough for the EL and the listeners (Jews) to solve the puzzle of the parable. EL and the listeners not only realise and understand one who loves his brother but go and do likewise. The term 'likewise' states the metaphorical intent of this parable. That is to say, understand and enforce the learning of this parable in everyday life that is so complex (multicultural).

\section{Discussion}

\subsection{Interpreting counsellor in the perspective of multicultural counselling competency}

The results of the dialogues between counsellor and EL in the parable of the Good Samaritan proved that the teacher (counsellor) had had a multicultural knowledge. The knowledge is related to the different view of two ethnics and religious views, which is between Jews and Samaritans. The counsellor also has had awareness about cultural values and their own biases as well as awareness of a counsellor about the worldview of counselee (EL). At this level, both the counsellor and the scribes were equally Jewish. However, they had different religious and cultural orientations.

In multicultural counselling, the kind of phenomena described above is categorized as cultural diversity. As [25] asserted, speaking of cultural diversity means refocusing dialogue on differences. The difference is related to gender, social status, economics, or religious orientation [25]. Likewise, with EL (counselee), knew the culture of the teacher (counsellor) carefully. There can be known by looking at lingual evident of the questions: "Teacher, what shall I do to inherit eternal life?"; And "who is my neighbour man?". These questions inform that counselee has considered counsellor to have capability and integrity to provide an answer in accordance with what is expected. 
This cultural diversity meeting can be regarded as a cultural episode, as the counsellor not only expressed interest in the facts about the counselee culture but also how the counselee saw the culture of counsellors, and their cultures as well. That statement is supported by the stamen of [26]. Cross-cultural counselling highlighting cultural phenomena that occur when cultural aspects of a counsellor, client's culture and counselling situations have joined together [26, p. 5]. The combination emerges a new paradigm of cultures as well as a unique experience of counselling.

Based on different religious orientations between the counsellor and counselee, the counsellor attempted to carry out his professional service to increase the multicultural awareness of the Samaritan (EL). In this phase, the counsellor had a multicultural awareness of the counselee culture, but on the other hand, the counsellor also had a multicultural awareness of the culture between counsellor and counselee (ethnicity and religiosity). This kind of cultural encounter is used by the counsellor to play an essential role in the framework of raising the multicultural consciousness of the Samaritans.

According to [27], individuals who have an awareness of diversity can develop an attitude of accepting, opening, and appreciating differences. Multicultural awareness is expected to be an adhesive for harmony in every interaction between individuals in their environment. There is in line with the opinion of [28], which states that social interactions in diverse groups require multicultural understanding (multicultural competencies).

\subsection{Multicultural counselling with the technique of parable}

The counsellor, as described before, delivered his assistance to raise the multicultural consciousness of the Samaritans. He applied multicultural counselling with parables technique (a culturally appropriate intervention strategy). It proves that the selection of the parable technique and the content of the story in the parable are exact since it matches the experience of life.

The story of the parable shows that the approaches and techniques employed by the counsellor were meant to improve the client's life. It was in accordance with the client's values and life experiences. Such phenomena of multicultural counselling are in accordance with what is stated by [26, p.10]. The phenomena, theoretically, is in accordance with five levels of cultural consciousness [29].

These are several things that need to be considered. First, the counsellor has data and information relating to the culture of the EL and the Samaritans. Data is the lowest level of information for the cognitive. It consists of 'signalsignals' or signs that should be proceeded more. At this level, it is stated that having data about a client's life is essential. With the data and information, the counsellor and counselee will have excellent communication.

Second, there must be a culture consideration. After having precise data and information about a culture, the counsellor will be able to gain an understanding of the culture and factors that become the values of a particular culture. There will 
consider the concepts that are held by a culture. It helps the counsellor to interpret the meaning of the existing cultural code. Furthermore, these cultural considerations will help counsellors to strengthen interaction processes

Third, there must be cultural knowledge. The importance of cultural knowledge for the counsellor is to help him/her facing any situation in counselling activities. This cultural knowledge is not only a knowledge of the culture of counselee but also to know the counsellor's own cultures. The goal is to open an understanding of the history of culture. These include major cultural issues such as groups, leaders, dynamics, cultural priorities and language skills to understand a specific culture.

Fourth, there must be a cultural understanding. After having cultural knowledge, cultural understanding is the next thing that should be mastered by a counsellor. The counsellor has to have a great understanding of his/her culture as well as the counselee's culture. It will lead to a deep awareness of the specificity of culture that gives understanding to the thought process, motivating factors, and other issues. The understanding will support the process of making a decision.

The last, a counsellor has to have cultural competency. Cultural competency is an understanding of culture adhesive. It is the highest level of cultural consciousness. Cultural competencies have a vital function, that is to help a counsellor in defining as well as making the right decision and cultural intelligence.

Furthermore, the application of the parable technique can move the counselee (EL) to think actively, imagining, and interpret the story to derive the meaning. There leads to multicultural consciousness (multicultural competence). Using a parable, a counsellor will not run the risk of forcing the counselee to make decisions or behave wrongly. Also, the counsellor will not run the risk of making a value assessment of the counselee. Moreover, the counselee would not be judged based on the moral or immoral standard.

Notably, a counsellor knows correctly that there are ethnicity and religiosity gaps, the counsellor should not offend the essential issue in interpersonal dialogue, or intrapersonal, as well as transpersonal dialogue. The counsellor has to receive a different cultural view, or in other words, the difference is not considered distorted by the counsellor [30]. Instead, the counsellor can require the counselee to answer counselee's question through a parable.

In the phenomena, counselling activity occurs as a learning process, transference, counter-transference and assessing activity. Both counsellor and counselee, through multicultural technique, will have attraction inference mutually, and there is no incongruence between perception and values. The statement is based on the fact that there is no distortion between two actors in the parable of Good Samaritan.

Getting back to Figure 2, based on the question from counselee, (a) "who is my neighbour?", which then the counsellor replied to the self-contemplatives, (b) "which of these three men do you think my neighbour man?", and then followed by the answer from counselee (c) "the man who has shown mercy to him", there is 
an interesting fact can be revealed. The revelation is seen from the order of the sentences.

Firstly, the counsellor was not at all offensive to the problems relating to mixed marriage or serving the gods, the place of the temple of God, etc. Secondly, the counsellor was also trying to stir up the compassion of EL by shifting the attention of the robbed/victim, to someone who has helped the victim.

With this parable, it is seen that the counsellor has conducted multicultural counselling toward EL until then he answered his question: "One who has shown 'compassion' to him". Here, the Samaritan show 'compassion' to the Jews by not allowing ethnic prejudice took place in his heart. 'Compassion' is an essential keyword in this parable because, with 'compassion', EL has got the cultural awareness of the Samaritans. Relating to 'compassion', Osborne explained that "Compassion is not a form of pity that is satisfied only by the expression of sorrow. The feeling of sorrow does not transcend to a feeling of compassion until there is a strong desire to help correct the cause of distress or suffering of another... the action can only measure our compassion it prompts. Basically, it translates our feeling into unselfish and sometimes sacrificial good deeds. To the extent we learn to put ourselves in another being's shoes, paws, hooves or daws, we will be able to demonstrate compassion." [30, p. 56].

A strong desire to help others, proper action, selflessness and sacrifice is the main characteristic of a man of mercy. The basis of mercy is the love of others, for loving others is a universally applied and unselective commandment [31]. The counsellor who has multicultural competencies understands clearly and firmly that the discussion relating to compassion (love) will not cause new problems relating to the difference in the socio-ethnicity/different religious values. Compassion can erase issues that occur in multicultural societies, such as prejudice, intolerance and discrimination. It will also wipe off self-independent, and promote self-interdependent. In fact, with the presence of mercy, there is no adverse reaction given by the EL to the counsellor when listening to the parable. As can be seen in the dialogue, EL gave a positive response.

The interesting thing about the multicultural counselling conducted by the counsellor through this parable is the acknowledgement of the Samaritans. EL accepts the position of his questioner (counsellor) and then EL as a proposing person. He recognized the right things by uttering "the one who showed compassion to him".

Recognition is indispensable in cultural diversity. Because of recognition, the diverse cultures appear parallel, harmonious and tolerance. Even though there is always the 'main culture' or majority culture that becomes mainstream in a community, the multicultural view will ensure the right of life, recognition and even understanding [26, p. 4]. Next, recognition, as read in the parable, must be based on compassion (love).

Compassion illustrates that the existence of man has always meant to be there-for-others. People cannot avoid the existence of 'The other'. If people avoid existence, they will lose the existence of a free and dignified individual. The parable of Good Samaritan makes the EL realised a multicultural scene. Hegel 
called the phenomena as dialectic in the concept of self-awareness. Wattimena states that self-awareness is always related to something outside the 'self' as the condition existence of such self-awareness. There is a condition referred to as a condition of interdependence, where the existence of others is directly related to some one's existence as a man, and vice versa [32].

Compassion as a basis for confession, reverence and acceptance can only be realized if people keep thinking openly and ready to understand 'the other'. The reaction of the Samaritan in the parable was an attitude that showed the capability of freeing subjective considerations and bringing the authentic experience of 'the other'. With the attitude performed by the Samaritan, the EL could finally see the world using the perspective of 'the other'. The EL, finally, has had an affective openness to the singularity and uniqueness of 'compassion'. Furthermore, this openness will also encourage a sense of obligation to meet the basic needs of 'the other'. Thus, through 'compassion', there will be a shift from self-independent to self-interdependent, that is to be there-for-others. People cannot avoid the existence of 'the other'.

\section{Conclusions}

A professional multicultural counsellor is a person who has multicultural knowledge, awareness of his/her culture as well as of counselee's culture. Furthermore, the counsellor must to have skill in applying the right approach or strategy in conducting multicultural counselling services. Based on a diacognitive analysis of the parable of the Good Samaritan, it was found that Jesus, as a counsellor as well as a teacher, was able to carry out the professional profession in conducting multicultural counselling services. Moreover, He was capable of using interpersonal, intrapersonal, transpersonal and intratextual dialogue. From the phenomena of counselling service using the parable of Good Samaritan, it can be seen that a competent counsellor has to be able to take a position as a questioner, an assessor and a storyteller.

The multicultural counselling technique used by the counsellor is a parable story. The parable can move imaginations and stimulate involvement. With the technique, a counsellor is hoped to succeed in helping a counselee. To be a multicultural success counsellor, one has to have compassion. The compassion practiced by the Samaritan to Jew who was dying could touch the cognitive and affective scribes. It, on one side, spurred the Samaritans with a strong desire to help others without considering the differences in ethnicity and religiosity. Compassion is capable of stimulating recognition, reverence and acceptance of different ethnicity and religiosity.

\section{References}

[1] A.A. Reza Wattimena, Studia Philosophica et Theologica, 11(1) (2011) 1-30.

[2] L. Ross, Adv. Exp. Soc. Psychol., 10(3) (1997) 174-221.

[3] B. Parekh, Rethinking Multiculturalism, Palgrave, New York, 2006, 3. 
[4] G. Sudarmanto, Teologi Multikultural. Departemen Multimedia YPPII Batu, Bidang Literatur, Batu Malang, 2014, 12.

[5] E. Nobet, A Search for The Origins of Judaism: From Joshua to Misnah, Sheffield Academic Press, Sheffield, 1997, 123.

[6] A.R. Anderson, Samaritans, ABD 5, 1992, 940-947.

[7] M. Mor, Samaritan History: The Persian, Hellenistic and Hasmonaean Period, A.D. Crown (ed.), J.C.B. Mohr (Paul Siebeck), Tubingen, 1989, 18.

[8] W.S. Wahona, Di Sini Kutemukan. BPK Gunung Mulia, Jakarta, 1986, 338-339

[9] F.P. Esler, Biblical Interpretation, 8(4) (2000) 325-357.

[10] S. Voorwinde, Vox Reformata, 24(76) (2001) 25-55.

[11] D. Permatasari, K. Bariyyah and C.E.N. Indrati, Jurnal Konseling Indonesia, 2(1) (2016) 22-28.

[12] M.E. DuPraw and M. Axner, Study Circles Recourse Center, (1997), 1-8.

[13] D.Y. Kağnıc1, Eurasian Journal of Educational Research, (44)(Summer) (2011) 111128.

[14] D. Wibowo and A. Prasetyo, Gema Teologi, 32(1) (2008) 23.

[15] C.Q. Wauran, Siapakah Sesamaku Manusia?. Sebuah Refleksi Atas Masalah Diskriminasi Etnis Tionghoa di Indonesia Berdasarkan Kisah Orang Samaria yang Murah Hati, Sekolah Tinggi Theologia Jaffray, Makasar, 2016, 1.

[16] P.N. Rule, HTS Theologies Studies/Theological Studies, 73(3) (2017) 7-8.

[17] P. Rule, Dialogue and Boundary Learning, Sense, Rotterdam, 2015, 35.

[18] P. Freire, Pedagogy of Indignation, Paradigm, Boulder (CO), 2004, 105.

[19] D. Nikulin, Dialectic and Dialogue, Stanford University Press, Stanford, 2010, 78.

[20] E. Matusov, Authorial Teaching and Learning, in Bakhtinian Pedagogy: Opportunities and Challenges for Research, Policy and Practice in Education Across the Globe, E.J. White \& M.A. Peters (eds.), Peter Lang, New York, 2011, 21-36.

[21] R. Zimmermann, Verbum Et Ecclesia JRG, 29(1) (2008) 269-292.

[22] R. Bauckham, New Testament Stud., 44(2) (1998) 475-489.

[23] G. Vermes, The authentic gospel of Jesus, Allen Lane, London, 2003, 125.

[24] W.D. Sue, Multicultural: Social Work Practice, John Wiley \& Son, Canada, 2006, 116.

[25] E.M. Wibowo, Konseling Multikultural di Abad-21, Prosiding Seminar Nasional Konvensi BK Ke-XX \& Kongres ABKIN Ke-XIII, Cabkin, Bandung, 2018, 1-28.

[26] D. Oparah, Make a World of Difference, Search Institute Publications, Minneapolis, 2006, 15.

[27] D. Matsumoto, People: Psychology from a Cultural Perspective, Wadsworth, California, 1994, 21.

[28] W. Wunderle, Through the Lens of Cultural Awareness: A Primer for US Armed Forces Deploying to Arab and Middle Eastern Countries, Combat Studies Institute Press, Fort Leavenworth (KS), 2006, 13.

[29] W.D. Sue, P. Arredondo and J. R. McDavis, J. Couns. Dev., 70(4) (1992) 477-486.

[30] A.C. Osborne, DVM News Magazine, October (2003) 54-56.

[31] A.C. Evans, Understanding The Bible Commentary Series Luke, Baker Books, Grand Rapids, 2011, 177.

[32] A.A. Reza Wattimena, Multikulturalisme Untuk Indonesia, Kanisius, Yogyakarta, 2010, 148. 